ECONOMICS



\title{
CONSUMERS' WILLINGNESS TO PAY FOR ORGANIC VEGETABLES: EMPIRICAL EVIDENCE FROM NEPAL
}

\author{
Kumar Bhattarai, \\ Department of Economics, \\ Patan Multiple Campus, \\ Tribhuvan University, Nepal \\ E-mail: \\ bhattarai1000@gmail.com
}

Received: December, 2018 1st Revision: April, 2019 Accepted: July, 2019

DOI: $10.14254 / 2071-$

789X.2019/12-3/9
JEL Classification: D02, O13, O17, P36, Q11
ABSTRACT. Due to undesirable health effects of conventional agricultural products, consumers are encouraged to prefer organic products. This study analyzes consumers' willingness to pay for organic vegetables in Kathmandu valley, Nepal, by applying single bounded dichotomous choice contingent valuation method. For this, the sample of 120 respondents was chosen randomly from four vegetable markets of Kathmandu valley. $94 \%$ of the respondents were found to be interested for organic vegetables whereas $86 \%$ were willing to pay for the offered bid premium. Majority of the respondents were found not to believe that vegetables available at their markets are really organically grown. The study has found that bid premium, education, household size, consumer perception about the presence of chemical residue in conventional vegetables and experience of suffering from vegetable borne diseases were the factors influencing consumers' willingness to pay a premium price for organic vegetables. The mean willingness to pay a premium price for organic vegetables was $25 \%$. As there is a market for organic vegetables in Kathmandu valley, there is a necessity for sufficient supply of such vegetables. Organic certification of vegetables by the government or related institutions may help increase consumers' confidence in organic vegetables.

Keywords: bid premium, Kathmandu valley, organic vegetables, single-bounded contingent valuation method, the willingness to pay

\section{Introduction}

Insect pests cause damage to agricultural products. Farmers spray synthetic pesticides to increase quantity and quality of such products. However, overuse and misuse of synthetic pesticides has negative consequences. Interest in organic food is increasing throughout the world as consumers are more concerned about food safety, environment, animal welfare and agricultural practices (Gregory, 2000; Grossman, 1972; Grunert \& Juhl, 1995; Harper \& Makatouni, 2002; Hughes, 1995; Schifferstein \& Oude Ophuis, 1997; Yiridoe, BontiAnkomah, \& Martin, 2005; Wandel \& Bugge, 1997). As a result, the market for organic food is growing and it is frequently regarded as one of the biggest growth market in food industry (Hughner, Mcdonagh, Prothero, \& Shultz II, 2007). The interest in organic food prompted 
numerous studies that compare organic and conventional foods in their various aspects (Yiridoe et al., 2005). Organic foods are found to be more nutritious, on average, than conventional foods (Benbrook, Zhao, Yanez, Davies, \& Andrews, 2008). Organic agriculture offers a responsible alternative to conventional agriculture due to its environmental, social and economic benefits (Morgera, Caro, \& Duran, 2012).

To control insects and diseases in agricultural products, farmers use different types of pesticides. The presence of pesticide residues has undesirable effects on human health and environment. Over 1000 pesticides may be used in agricultural products (Ortelli, Edder, \& Carvi, 2004) but the list of those pesticides used in agricultural products are usually not known to final consumers (Stan, 2000). Food safety from contamination of pesticide residues is of great concern throughout the world. Due to undesirable health effects from conventional agricultural products, consumers are often encouraged to purchase organic products. The use of pesticides and fertilizers is widespread in Nepal and it is increasing at faster rate with the intensificated commercialization of agricultural production, which is resulting in several problems including pests' resistance to pesticides, elimination of natural enemies of pests, environmental pollution, depletion of soil fertility, toxic residues in food and feed materials, disruption of the ecosystem, animal and human hazards and other economic losses (Pokharel \& Pant, 2009). Such a situation is encouraging production and consumption of organic products.

Directive for national technical standards of organic agriculture production and processing system (2007) regulates organic market in Nepal. This directive defines the standards of organic agriculture. These standards include: provision of a buffer zone between organic and conventional production area (which must be at least 5 meters, however it can be 4 meters if there is a road between the areas); no use of chemical fertilizers, enzymes/hormones and pesticides in agriculture production; provision of a conversion period; the use of seeds of local varieties (whenever possible) and with organic certification; and no use of genetically modified organism and living modified organism seeds among others (GON, 2008).

In Nepal, consumption of organic foods covers only a few percentage of the total food consumption in the country (Aryal, 2008; Rana Bhat, 2008), however, it is increasing these days, especially in Kathmandu valley, Chitwan and Pokhara (Aryal, Chaudhary, Pandit, \& Sharma, 2009). The areas under organic farming, production of organic goods and export of such goods to foreign countries are increasing in Nepal (Adhikari, 2009). The major organic products grown in Nepal are tea, coffee, large cardamom, ginger, honey, herbal products and vegetables (Pokharel \& Pant, 2009). In Kathmandu valley, the major organic products demanded are vegetables followed by cereals and pulses (Aryal et al., 2009). Nepal has diverse agro-eco-zone, which is an advantage for farmers producing different types of vegetables, both season and off-season ones.

Despite the increasing production and consumption of organic products in Nepal, very little empirical studies exist on the related consumer demand. The absence of such studies is creating uncertainties for the farmers producing such products. Organic production is more labour intensive than conventional production and the use of other organic inputs is also more costly (Boys, Willis, \& Carpio, 2014). Production in small scale is also responsible for higher cost of production. Organic production results in greater produce losses to diseases and insects (Govindasamy, DeCongelio, \& Bhuyan, 2008). Due to such reasons, consumers should pay a premium price for organic products. So, there is a necessity of conducting studies on what consumers are willing to pay for organic products. The objectives of this study are: to assess the current situation with consumption of organic vegetables in Kathmandu Valley, to measure consumers' willingness to pay a premium price for organic vegetables in Kathmandu Valley and to determine the factors influencing consumers' willingness to pay a premium price for organic vegetables in Kathmandu Valley. Measurement of consumers' willingness to pay for 
organic vegetables may benefit policy makers as well as farmers. Policy makers can know the choice of consumers and hence develop appropriate policies to promote the production of organic vegetables. Similarly, farmers can realize the willingness to pay a premium price for such vegetables. Accordingly, they can make appropriate production plans. To analyze consumers' demand for organic vegetables, contingent valuation method was used. Many researchers from different countries have used this method to assess consumer demand for organic vegetables.

This paper consists of five sections. Section 1 introduces the study. It defines the objectives and highlights the importance of this study. Section 2 reviews the literature related to the willingness to pay for organic products. Section 3 describes the methodology used in the study. Section 4 presents the results and discusses them. Section 5 concludes the study.

\section{Literature Review}

Nandi, Bokelmann, Gowdru, and Dias (2016) analyzed the factors influencing consumers' willingness to pay for organic fruits and vegetables in India. To elicit consumers' willingness to pay, the contingent valuation method was applied. Logit model was estimated to identify the determinants of willingness to pay. For this, data were collected from 250 respondents in Bangalore. Study found that 90 percent and 74 percent respondents were willing to pay premium price for organic vegetables and fruits respectively. The aggregate percentage of those who were willing to pay for 5 percent to 25 percent premium price for fruits and vegetables were 58 percent and 81 percent respectively. The determinants of willingness to pay for organic fruits and vegetables were identified as consumers' perception about presence of chemical residue in conventional fruits and vegetables, consumers' trust on retailers to buy organic fruits and vegetables, perception of beneficial influence of organic products on environment, monthly household income, perception of higher nutritional value in organic fruits and vegetables, availability of organic fruits and vegetables in the market, household size and gender of respondent. Researchers conclude that the reasons behind higher willingness to pay a premium price for organic vegetables than for organic fruits may be due to meager availability of organic fruits in the market and consumers' perception that there is less application of chemical pesticides on fruits compared to vegetables.

Sriwaranun, Gan, Lee, and Cohen (2015) analyzed the consumers' willingness to pay for organic products in Thailand. The willingness to pay a premium price for vegetables, rice and meat was elicited by applying contingent valuation method. Data were collected from 502 respondents of Bangkok metropolitan area by applying convenience sampling method. Study found that 96.8 percent respondents were willing to pay a premium price for organic products. Consumers were willing to pay a high percentage premium for organic vegetables whereas low percentage for organic rice and meat. The mean willingness to pay for organic vegetable was $56.53 \mathrm{Baht} / \mathrm{Kg}$, which was 88 percent higher than the price of conventional vegetables. For organic rice, the mean willingness to pay was $211.71 \mathrm{Baht} / 5 \mathrm{Kg}$ packs, which was 51 percent more than the conventional rice price. Similarly, in case of organic meat, the mean willingness to pay was $135.95 \mathrm{Baht} / \mathrm{Kg}$, which was 51 percent higher than the price of conventional meat. The factors influencing willingness to pay a premium price for organic vegetables were experience in purchasing organic products, health consciousness, environmental concern, perception of quality and health benefits of organic products, households with children younger than 18 years and monthly household income. The factors influencing willingness to pay for rice were experience in purchasing organic products, food ethical concern, perception of quality and health benefits of organic products, households with children younger than 18 years, respondents aged 55 years and older and respondents residing in city. Similarly, experience in purchasing organic product, food ethical concern, environmental concern, perception of quality 
and health benefits of organic products, knowledge about organic product and respondents residing in city were found to influence the willingness to pay for organic meat. Researchers suggest to the marketers and producers to reduce the price of organic products to encourage people to purchase such products.

Narine, Ganapat, and Seepersad (2015) analyzed the consumers' willingness to pay for organic tomato in Trinidad. Data were collected from five most populated geographical areas of Trinidad, i.e. North East, North West, Central, South East and South West by applying contingent valuation method. To collect data, 405 randomly selected respondents were interviewed. Logistic regression was used to estimate factors influencing willingness to pay a premium price for organic tomato. Consumers were found to be willing to pay premium price of 20 percent for organic tomato compared to the price of conventional tomato. Gender, area of residence, level of education, level of income and perceived health benefits were the factors influencing willingness to pay a premium price for organic tomato. Study concludes that there is marketing potential for organic tomato in Trinidad. Researchers suggest to establish organic regulatory board for the formal farm inspection, product testing and farm certification.

Coulibaly, Nouhoheflin, Aitchedji, Cherry, and Adegbola (2013) analyzed consumers' perceptions and willingness to pay for organically grown cabbage and tomato in two countries Ghana and Benin by employing hedonic-pricing model. For this, cross-sectional data were collected from a sample of 100 consumers in the markets of each country. In Ghana, data were collected from Accra and Tema whereas in Benin data were collected from Cotonou and GrandPopo. Study found that 86 percent of consumers in Ghana and 95 percent consumers in Benin were willing to pay a premium price for organically produced vegetables. Consumers were willing to pay 57 percent more for organic cabbage and 50 percent more for organic tomato in Ghana whereas 66 percent more for cabbage and 56 percent more for tomatoes in Benin. The determinants of willingness to pay for organic cabbage in Ghana were found to be level of education, awareness of synthetic pesticides on vegetables and expected taste of the vegetables treated with organically based pesticides whereas in Benin, the determinants of willingness to pay for organic cabbage were level of education, awareness of health risks, availability of organically grown vegetables throughout the year and level of chemical residue in cabbage. Similarly, in case of organic tomato, the determinants of willingness to pay in Ghana were chemical residues, taste of tomatoes and appearance of tomatoes whereas in Benin, the determinants were level of income, pesticide residues, awareness of health risks due to pesticide residues and availability of tomato treated with organically based pesticides. Researchers conclude that in both countries there is potential demand for organic cabbage and tomato.

Aryal et al. (2009) analyzed the consumers' willingness to pay for organic products in Kathmandu valley. Data were collected from 180 respondents. For this, consumers were classified into six types. They were: teachers, NGO/INGO workers, health professionals, government officials, businessmen and general public. From each of these groups, 30 individuals were selected purposively for the collection of data. All of the respondents were found to be willing to pay a premium price for organic products. Study found that 90 percent of the respondents had knowledge about organic products. Researchers analyzed the preference of respondents for different types of organic products. Among 180 respondents, 42 percent respondents' first choice was vegetable followed by pulses ( 28 percent), fruit ( 20 percent) and rice (10 percent). On average, consumers were willing to pay a premium price of 30 percent for organic products compared to the price of conventional products.

Thus, different researchers, in different countries, have studied about the willingness to pay for organic products. The use of contingent valuation method is very popular among the researchers to measure the willingness to pay for a premium price. Literature review suggests that the willingness to pay a premium price is different for different products in different countries. Similarly, the factors influencing willingness to pay a premium price are also 
different in different countries. However, the empirical studies that measure consumers' willingness to pay a premium price and estimate determinants of willingness to pay for organic fruits and vegetables in Nepal are extremely scanty. The major contribution of this study, compared to previous studies related to organic products in Kathmandu valley, is that this study applies reliable method of analysis, i.e. contingent valuation method. Similarly, data were collected from randomly selected respondents. Thus, the valid conclusion is derived from this study.

\section{Methodology}

\subsection{Theoretical Framework of Contingent Valuation Method}

This study was based on contingent valuation method (CVM), which is a survey-based method. In this method, respondents are directly asked questions regarding how much they would be willing to pay for perceived benefits from a good or service in a hypothetical market situation (Nandi et al., 2016). Thus, to apply CVM, it is necessary to create hypothetical market for the good or service to be evaluated. This method has been widely used in the measurement of willingness to pay (WTP) of consumers for non-market goods (Chuen-Khee \& Othman, 2010). It is the reliable method to collect useful information (Arrow, Solow, Portney, Radner, \& Schuman, 1993). Under this method, there are different approaches to measure WTP. They are: open-ended question approach, iterative bidding approach, payment card approach and dichotomous choice approach (Bhattarai, Pathak, \& K. C., 2017). This study was based on dichotomous choice approach, which is the most popular among the practitioners (Calia \& Strazzera, 2000). Commonly used methods under dichotomous choice CVM are singlebounded and double-bounded methods. This study was based on single-bounded CVM, where respondents are asked whether they are willing to pay a fixed amount of money for the item under evaluation and if the response is yes, follow-up question is asked for the maximum amount they are willing to pay whereas if the answer is no, follow-up question is asked to know what amount of money they are willing to pay for the item being evaluated (Bhattarai et al., 2017; Boyle, 1990).

Contingent valuation data can be modeled as follows (Alberini, 1995):

The model for WTP is $Y_{i}^{*}=X_{i} \beta+\varepsilon_{i}$

Where, $Y_{i}^{*}$ is willingness to pay variable, $\varepsilon$ is a zero-mean error term, and the plan and individual characteristics are summarized into $1 \times \mathrm{K}$ vector $X_{i}$.

The statistical model for the observables expresses the likelihood that respondent will agree on proposed amount, given the plan and individual characteristics. That probability is $\operatorname{Pr}\left(Y_{i}^{*} \geq C_{i} \mid X_{i}\right)=1-G\left(C_{i} \mid X_{i}\right)$, where $\mathrm{G}$ is distribution function (cdf) of $Y^{*}$. $Y^{*}$ is assumed to be normal or logistic. The probability of "yes" to a payment of $\$ \mathrm{C}$ is $\operatorname{Pr}\left(Y_{i}=1\right)=E\left(Y_{i}\right)=$ $\operatorname{Pr}\left(Y_{i}^{*} \geq C_{i}\right)=1-F\left(\left(C_{i}-X_{i} \beta\right) / \sigma\right)$, where $Y_{i}$ takes on a value of one if respondent accepts the offer $\mathrm{C}_{\mathrm{i}}$ (and zero otherwise), $\mathrm{F}$ is the cdf of $\varepsilon / \sigma$, and $\sigma$ is scale parameter of distribution of $Y^{*}$. The probability of declining to pay proposed amount is $\operatorname{Pr}\left(Y_{i}^{*} \leq C_{i}\right)=\mathrm{F}\left(\left(C_{i}-X_{i \beta}\right) / \sigma\right)$.

\subsection{Logistic Regression}

To determine the factors influencing consumers' willingness to pay a premium price for organic vegetables in Kathmandu Valley, the relationship between explanatory variables and willingness to pay a premium price was modeled by using logistic regression. The explanatory variables were bid premium, education, household size, monthly household income, consumer perception about presence of chemical residue in conventional vegetable and experience of 
suffering from vegetable borne diseases. The description of explanatory variables is shown in table 1. The logistic regression can be estimated by applying method of maximum likelihood, where the log likelihood function is (Alberini, 1995):

$$
\sum_{i=1}^{n}\left\{Y_{i} \log \left[1-F\left(\frac{C_{i}-X_{i} \beta}{\sigma}\right)\right]+\left(1-Y_{i}\right) \log F\left(\frac{C_{i}-X_{i} \beta}{\sigma}\right)\right\}
$$

The mean WTP was computed by following the procedure explained by Jeanty (2007).

Table 1. Description of explanatory variables used in the model

\begin{tabular}{llcc}
\hline Variable & Description & Mean & VIF \\
\hline Bid premium & $\begin{array}{l}\text { Respondents were offered bid premium of 10\%, 20\%, } \\
30 \%, 40 \%, 50 \% \text { and 60\% }\end{array}$ & $35 \%$ & 1.43 \\
\hline Education & $\begin{array}{l}\text { Highest level of education attained by respondent } \\
\text { measured on 7 points scale: no degree achieved =1, } \\
\text { secondary education =2, higher secondary level =3, } \\
\text { bachelor degree =4, master's degree =5, M.Phil. } \\
\text { degree =6, doctorate degree =7 }\end{array}$ & & \\
& $\begin{array}{l}\text { Total number of people living in respondent's } \\
\text { household }\end{array}$ & 5.6 & 1.03 \\
\hline Household size & Monthly household income of respondent & Rs 41,082 & 1.83 \\
\hline $\begin{array}{l}\text { Income } \\
\begin{array}{l}\text { Consumer perception } \\
\text { about presence of } \\
\text { chemical residue } \\
\text { conventional vegetable }\end{array}\end{array}$ & Yes=1, no=2, don't know=3 & 1.2 & 1.80 \\
\hline $\begin{array}{l}\text { Experience of suffering } \\
\text { from vegetable borne } \\
\text { disease }\end{array}$ & Yes=1, no=2, don't know=3 & 2 & 1.26 \\
\hline Mean VIF & & & \\
\hline
\end{tabular}

Source: Author's computation from survey data, 2018

Residuals were not found to be normally distributed. Due to which, probit model could not be used. In such situation, logistic regression was used to analyze the relationship between aforementioned explanatory variables and consumers' willingness to pay a premium price for organic vegetables. Multicollinearity, among the explanatory variables, was tested by estimating variance inflation factor (VIF). As the VIF values, for each variable, are less than 10 and mean VIF is 1.48 , there was no multicollinearity among the explanatory variables.

\subsection{Study Area and Sampling Method}

This study was conducted in Kathmandu Valley. There are many vegetable markets in Kathmandu Valley. Among them four markets were selected for the study. They are Kalimati fruits and vegetable market, Balkhu agriculture vegetables market, vegetable and fruit market Lagankhel and Kausaltar market. Balkhu and Kalimati vegetables markets are located in Kathmandu district whereas Lagankhel and Kausaltar markets are located in Lalitpur and Bhaktapur districts respectively. Thus, data were collected from three districts of Kathmandu valley. 120 respondents were interviewed from these markets. From each of these markets 30 respondents were interviewed. As there was no sampling frame of consumers, the enumerators went to each market and randomly selected 5 sellers of vegetables in each market. After briefing consumers, about the study, of each seller, data were collected from every $4^{\text {th }}$ consumer. In the situation of not opting for interview by selected $4^{\text {th }}$ consumer, the immediate next respondent 
was approached. This method is expected to be helpful to ensure the random selection of interviewee in the study.

\subsection{Survey and Questionnaire Design}

Data were collected by using structured questionnaire. While designing questionnaire, recommendations of Arrow et al. (1993) and Mitchell and Carson (1989) were followed. Scoping survey was conducted before designing questionnaire. Then, on the basis of scoping survey, draft questionnaire was prepared. Such prepared questionnaire was pre-tested in the pilot survey of 20 consumers of four vegetable markets. Based on the result and feedback of pilot survey, questionnaire was finalized.

There were five sections in the questionnaire. The first section includes the questions related to identification of the respondent, i.e. name of respondent and contact number. The second section includes the questions related to consumption of organic vegetables. The third section presented the contingent valuation scenario. The forth section was related to demand assessment for organic vegetables. The fifth section involves socio-economic and demographic information of respondent. Both quantitative and qualitative information were collected. To meet the requirement of study, the contingent valuation scenario was designed as follows:

'Efforts are being made to make regular provision of organic products in the market on the basis of demand for these products. Organic vegetables have higher cost of production compared to conventional vegetables. It is more labour intensive than conventional production and use of other organic inputs is also more costly (Boys, Willis, \& Carpio, 2014). Production in small scale is also responsible for higher cost of production. Organic production results in greater produce losses to diseases and insects (Govindasamy, DeCongelio, \& Bhuyan, 2008). Due to such reasons, consumers should pay a premium price for organic products if they have to consume such products.'

Based on the scoping survey and pilot survey, six different bid premiums were determined as $10 \%, 20 \%, 30 \%, 40 \%, 50 \%$ and $60 \%$. The study measured mean willingness to pay a premium price for organic vegetables. Similarly, factors influencing willingness to pay a premium price were also identified. Logit model was used to determine the factors influencing willingness to pay a premium price for organic vegetables.

\subsection{Data Collection and Analysis}

Mainly primary sources of information were used in the study. For this, cross-sectional data were collected from 120 respondents. Data were collected from August 19, 2018 to September 1, 2018. However, based on the requirement of study secondary sources of information were also used. Then, they were asked whether they were willing to pay a premium price for organic vegetables. While collecting data, hypothetical market was presented to the respondents. Here, premium price refers to the maximum difference in price that the consumers were willing to pay for the organic vegetables over the conventional vegetables. In case of "yes" response, particular bid premium was offered. When bid premium was accepted, follow-up question was asked to know maximum premium price respondents were willing to pay. On the other hand, when offered bid premium was rejected, follow-up question was asked to find the level of premium price they were willing to pay. Furthermore, when the response was "no" on willingness to pay question, follow-up question was asked behind not willing to pay. Only final consumers of vegetables were interviewed.

Socio-economic and demographic characteristics of respondents were analyzed by using descriptive statistics. Graphical approach was also used for the purpose of analysis. The 
logit model was estimated to identify the factors influencing willingness to pay a premium price. Data were analyzed by using software package STATA version 13.

\section{Results and Discussion}

\subsection{Socio-economic and Demographic Features of Respondents}

Among 120 respondents, 98 were male whereas 22 were female. Some female respondents, who were approached for interview, refused to give interview. In such situation, immediate next respondent was approached and interviewed. The eldest consumer was of 65 years whereas the youngest was of 17 years. The average age of respondents was 38 years. 6 respondents had not received formal educational degree whereas 19 respondents had secondary level educational qualification. Similarly, 27, 38, 29 and 1 respondent(s) had received higher secondary level, bachelor degree, master's degree and doctorate degree respectively. None of the respondents had received M.Phil. degree. 96 respondents were married whereas 24 were unmarried.

Table 2. Socio-economic and demographic features of respondents

\begin{tabular}{ll}
\hline Variable & Respondents \\
\hline Sex & 98 \\
\hline No. of male respondents & 22 \\
No. of female respondents & 38 \\
\hline Age & 65 \\
\hline Average age & 17 \\
Maximum age & \\
Minimum age & 6 \\
\hline Educational level & 19 \\
\hline No degree achieved & 27 \\
Secondary education & 38 \\
Higher secondary education & 29 \\
Bachelor degree & 0 \\
Master's degree & 1 \\
M.Phil. degree & \\
Doctorate degree & 96 \\
\hline Marital status & 24 \\
\hline Married & \\
Unmarried & 5 \\
\hline Size of household & 11 \\
\hline Average size & 2 \\
Highest size & 41,082 \\
Lowest size & 600,000 \\
\hline Monthly household income (Rs) & 2,000 \\
\hline Average monthly income &
\end{tabular}

Source: Field survey, 2018

Similarly, the highest household size was 11 whereas lowest was 2 . The average household size was 5. The highest monthly household income was Rs 600,000 whereas the lowest was Rs 2,000. The average monthly household income was Rs 41,082. Rupees (Rs) is currency of Nepal. 


\subsection{Current Situation of Consumption of Organic Vegetables in Kathmandu Valley}

In the survey, question was asked, to the respondent, on whether they had heard about the organic vegetable. Among the respondents, 92 percent were found to have heard about the organic vegetables. Only 8 percent respondents had not heard about organic vegetables. Regarding availability of organic vegetables in the market, 12 percent respondents said that it is easily available in the market whereas 76 percent said that it is not easily available. Remaining 12 percent responded that they do not know about the availability of such vegetables in the market. Study found that 71 percent respondents had experience of consuming organic vegetables whereas 29 percent had not such experience. On average, consumers were found to be consuming organic vegetable since last 11 years. At a maximum, consumers were consuming organic vegetables since last 40 years whereas at a minimum, consumers were consuming since last 1 month.

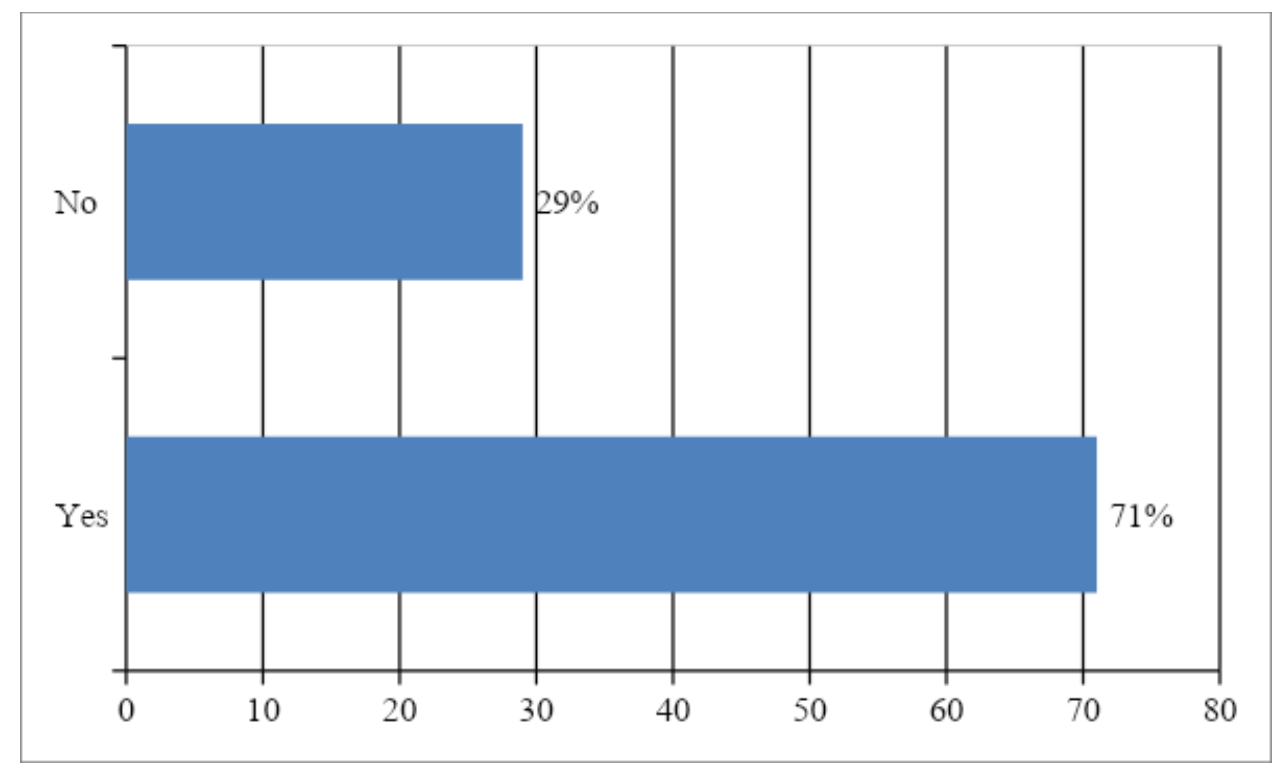

Figure 1. Consumption of organic vegetables

Source: Field survey, 2018

Tomato, pumpkin, cabbage, cauliflower, potato, onion, capsicum, bitter melon, garlic, bottle gourd, asparagus, brinjal, broccoli, carrot, mustard green, radish, spinach, green beans, yardlong beans, chili pepper, etc. were the organic vegetables consumed by the respondents. However, most of the consumers said that, out of the total consumption of vegetables, the amount of organic vegetable consumed is very low. This may be due to the reason that organic vegetables are not easily available in the market.

\subsection{Consumers Willing and Unwilling to Pay a Premium Price for Organic Vegetables in Kathmandu Valley}

Among the respondents, 94 percent were interested for the organic vegetables whereas 86 percent were willing to pay for offered bid premium. Thus, vast majority of respondents were interested to pay higher price for organic vegetables compared to conventional vegetables. Similar results were found by different researchers in their studies. Boys et al. (2014) found that 87.7 percent consumers were willing to pay a price premium for organic products in Dominica. Similarly, Coulibaly et al. (2011) found that 86 percent consumers in Ghana and 95 percent in Benin were willing to pay a premium price for organically grown vegetables. 
In the survey, six different bid premiums (10 percent, 20 percent, 30 percent, 40 percent, 50 percent and 60 percent) were offered to the respondents. Each bid premium was offered to 20 respondents. The lowest bid premium (10 percent) was accepted by 93 percent respondents. Similarly, 20 percent, 30 percent, 40 percent and 50 percent bid premiums were accepted by 90 percent, 58 percent, 57 percent and 41 percent respondents respectively. The highest bid premium (60 percent) was accepted by only 25 percent respondents. Clearly, with the increase in bid premium, the willingness to pay a premium price for organic vegetables declined.

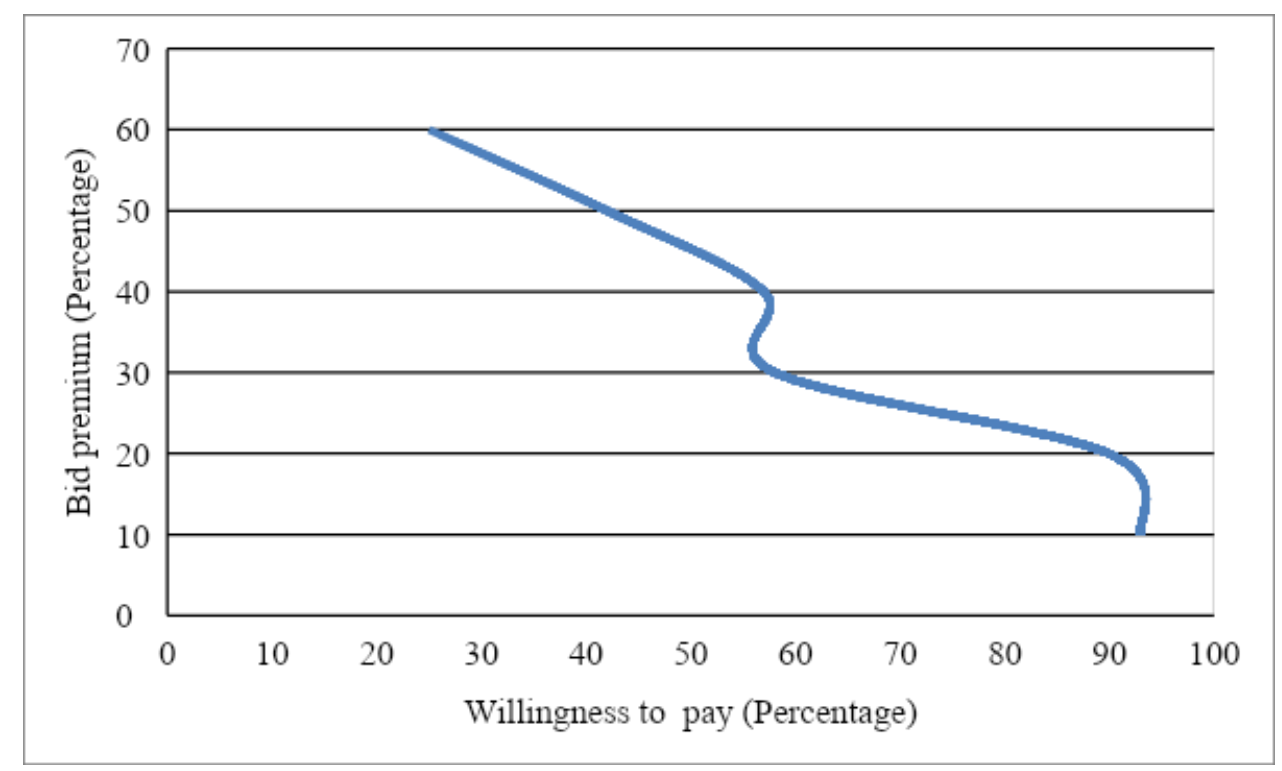

Figure 2. Effect of increase in bid premium on willingness to pay a premium price for organic vegetables

Source: Field survey, 2018

6 percent respondents were not willing to pay a premium price for organic vegetables. Question was asked to the respondents behind not willing to pay. They said that payment of premium price is not affordable.

\subsection{Consumers' Perception Regarding Pesticide-Treated Vegetables}

Question was asked, to the respondents, whether pesticide-treated vegetables, which are available in the market, contain chemical residue. Vast majority of respondents, i.e. 88 percent said that such vegetables contain chemical residue. 4 percent respondents said that there is not chemical residue in such vegetables whereas 8 percent displayed their ignorance on this question. Follow- up question was asked, to the respondents who said that pesticide-treated vegetable contain chemical residue, regarding the intensity of problem, which was measured in a scale of 1 to 5 with 1 indicating very high, 2 high, 3 moderate, 4 low and 5 very low. 18 percent respondents considered chemical residue as a very high problem, 25 percent considered as a high problem, 35 percent as moderate problem, 10 percent as a low problem and 12 percent as a very low problem. 


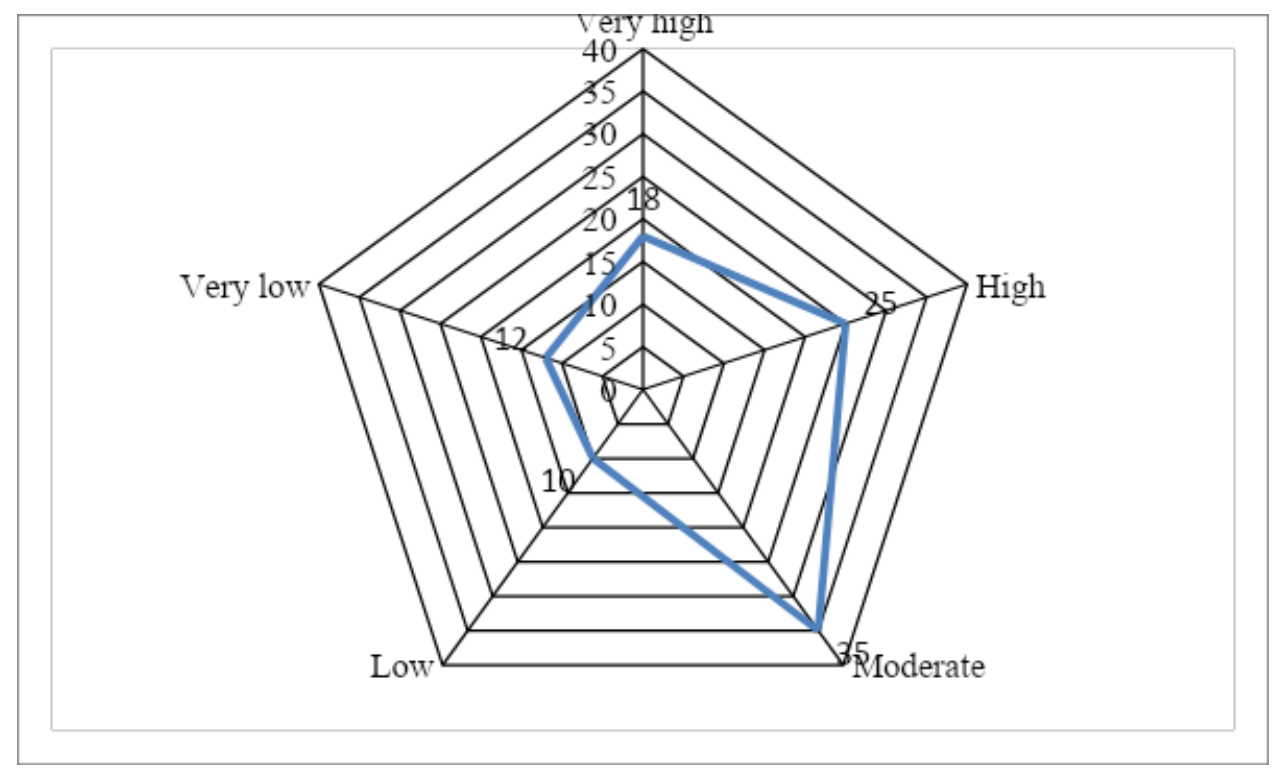

Figure 3. Intensity of problem as reported by respondents (in percent)

Source: Field survey, 2018

Among the respondents who responded intensity of problem as very high, high, moderate and low; 95 percent, 90 percent, 85 percent and 50 percent were, respectively, willing to pay a premium price for organic vegetables whereas those who responded as very low were not willing to pay. Thus, even those people who considered the intensity of problem as moderate and low were also willing to pay premium price for organic vegetables. It shows that there is market for organic vegetable in Kathmandu valley.

Study found that 25 percent respondents had experience of suffering from vegetable borne disease from the consumption of synthetic pesticide-treated vegetables whereas 56 percent respondents found to have no such experience. Remaining 19 percent respondents displayed their ignorance on this issue.

\subsection{Consumers' Perception Regarding Organic Vegetables Available in Market}

53 percent consumers were found not to believe that the vegetables which are available in the market, as organic, are really organically grown. Those respondents argued that it's not possible to the consumers to check whether the available vegetables, in the market, are really organically grown. Respondents focused on necessity of organic certification, of such products, by the government. Only 21 percent were found to believe that vegetables are really organically grown whereas remaining 26 percent displayed their ignorance on the question asked. Similarly, 86 percent respondents said that organic vegetables are tastier than conventional vegetables. 1 percent respondents said that conventional vegetable is tastier than organic vegetable whereas 11 percent said that both organic and conventional vegetables are equally tastier. Two percentage respondents displayed their ignorance on the question asked.

93 percent respondents said that organic vegetables have higher nutritional value compared to conventional vegetables whereas 5 percent said that both types of vegetables have equal nutritional value. 2 percent respondents displayed their ignorance on the question asked.

Environmental awareness of consumers was also analyzed during the survey. Consumers were asked whether growing vegetables organically contributes in the environmental protection. As such type of vegetable production does not use synthetic pesticides; it contributes in the protection of environment. Survey found that 90 percent 
respondents were environmentally aware. 6 percent respondents found to be environmentally unaware where 4 percent respondents displayed ignorance on the question asked.

\subsection{Estimation of Logit Model}

To analyze the factors influencing consumers' willingness to pay a premium price for organic vegetables, logistic regression was employed. Table 3 shows result of logistic regression. The Pseudo R-Squared is 0.4405 .

Table 3. Logit regression result

\begin{tabular}{llll}
\hline Variable & Coefficient & Standard error & Marginal effect \\
\hline Constant & 12.16292 & 2.636925 & \\
\hline Bid premium & $-.043553^{* * *}$ & .0123701 & -.0116544 \\
\hline Education & $.2261195^{* * *}$ & .0537062 & .0395167 \\
\hline Household size & $-.1858893^{* * *}$ & .0491755 & -.0243189 \\
\hline Income & .3162157 & .2377561 & $1.88 \mathrm{e}-06$ \\
\hline Presence of chemical residue & $3.452863^{* *}$ & 1.5012447 & .1322003 \\
\hline Suffering from disease & $1.366947^{* *}$ & .5298244 & .1245215 \\
\hline Mean WTP a premium price (percentage) & & \\
\hline Mean WTP & 25 & \\
\hline
\end{tabular}

$$
{ }^{* * *} \mathrm{p}<0.01,{ }^{* *} \mathrm{p}<0.05
$$

Result shows that there is negative and significant effect $(\mathrm{p}<0.01)$ of bid premium on the WTP. It shows that with the increase in premium price offered, the willingness to pay decreased. The marginal effect shows that an increase in bid premium by 10 percent reduces probability of WTP a premium price by 1.17 percent. Education has positive and significant effect $(\mathrm{p}<0.01)$ on WTP. Thus, with the increase in level of education of respondent, the amount that respondent is willing to pay is also increasing. The finding is reasonable because educated people know the importance of organic vegetables and want to pay more than the uneducated people. This finding is supported by Diaz, Pleite, Paz, and Garcia (2012). The marginal effect suggests that an increase in educational attainment by one level leads to increase in WTP a premium price by 3.95 percent. Household size has negative and significant effect $(\mathrm{p}<0.01)$ on the WTP, which shows that larger household size respondents were willing to pay less than small household size respondents. The result seems reasonable because in the larger size households it requires more spending in organic vegetables, which is difficult to manage. Similar type of result was found by Nandi et al. (2016). The marginal effect shows that an increase in household size by one person reduces WTP by 2.43 percent. Monthly household income has positive but insignificant effect on WTP. Consumer perception about presence of chemical residue in conventional vegetable has positive and significant effect $(p<0.05)$ on WTP. This result is in line with Nandi et al. (2016). The marginal effect shows that consumers who believed that pesticide-treated vegetables contain chemical residue were 13.22 percent more likely to pay premium price for organic vegetables than those consumers who did not believe. Experience of suffering from vegetable borne disease has positive and significant effect $(\mathrm{p}<0.05)$ on WTP a premium price. This shows that those respondents who suffered from vegetable borne disease after consumption of conventional vegetable were willing to pay for safer vegetables than those without such experience. Marginal effect shows that consumers who were suffered from synthetic pesticide-treated vegetables were 12.45 percent more likely to pay premium price for organic vegetables than those who did not suffered from such diseases. 


\section{Conclusion}

Study found that 94 percent respondents were interested for organic vegetables whereas 86 percent were willing to pay for offered bid premium. Consumers were found to be aware of harmful effects of conventional vegetables. Most of the respondents thought that organic vegetables are tastier than conventional vegetables. Vast majority of respondents thought that organic vegetables have higher nutritional value than conventional vegetables. The mean willingness to pay a premium price for organic vegetables is 25 percent. Thus, consumers are ready to pay higher price for organic products if those products are available in the market. This shows that there is market for organic vegetables in Kathmandu valley. In such situation, priority should be given to the sufficient supply of organic vegetables. If government could support in the production of such vegetables, farmers will be motivated to produce the organic vegetables. If organic vegetable is produced in more organized way and in large scale, average cost of production may fall so that the market will be further enhanced. This study was based on organic vegetables only. There is scope of research on consumers' willingness to pay for organic fruits also.

\section{Acknowledgement}

This paper is a part of research entitled 'Consumers' Willingness to Pay for Organic Vegetables in Kathmandu Valley', which was conducted by Kumar Bhattarai. The financial support for the study was provided by University Grants Commission, Nepal.

\section{References}

Adhikari, R.K. (2009). Economics of organic vs inorganic carrot production in Nepal. The Journal of Agriculture and Environment, 10. Kathmandu: Ministry of Agriculture and Cooperatives.

Alberini, A. (1995). Optimal designs for discrete choice contingent valuation surveys: singlebound, double-bound, and bivariate models. Journal of Environmental Economics and Management, 28, 287-306. doi: 10.1006/jeem.1995.1019

Arrow, K., Solow, R., Portney, P.R., Leamer, E.E., Radner, R., \& Schuman, H. (1993). Report of the NOAA Panel on Contingent Valuation. Federal Register, 58(10): 4601-4614. Retrieved from http://www.economia.unimib.it/DATA/moduli/7_6067/materiale/noaa\%20report.pdf

Aryal, K.P. (2008).General perceptions of producer, traders and consumers about organic products in Kathmandu valley. In P. Chaudhary, K. Aryal, \& D. Tharu (Eds.), Opportunities and Challenges of Organic Production and Marketing in South Asia. Paper presented at the national Policy Dialogue, pp. 120-124. Kathmandu: NPG.

Aryal, K.P., Chaudhary, P., Pandit, S., \& Sharma, G. (2009). Consumers' willingness to pay for organic products: A case from Kathmandu valley. The Journal of Agriculture and Environment, 10. Kathmandu: Ministry of Agriculture and Cooperatives.

Benbrook, C., Zhao, X., Yáñez, J., Davies, N., \& Andrews, P. (2008). New evidence confirms the nutritional superiority of plant-based organic foods. Retrieved from https:/lorganiccenter.org/reportfiles/Nutrient_Content_SSR_Executive_Summary_FINAL.pdf

Bhattarai, K, Pathak, B., \& K.C., B. (2017). An analysis of households' demand for improved solid waste management in Birendranagar municipality, Nepal. International Journal of Energy Economics and Policy, 7(4), 83-89. Retrieved from http://www.econjournals.com/index.php/ijeep/article/view/5354 
Boyle, K.J. (1990). Dichotomous-Choice, Contingent-Valuation Questions: Functional Form Is Important. Northeastern Journal of Agriculture and Resource Economics, 19(2), 125131. Retrieved from http://purl.umn.edu/29039

Boys, K.A., Willis, D.D., \& Carpio, C.E. (2014). Consumer willingness to pay for organic and locally grown produce on Dominica: Insights into the potential for an organic island. Environment, Development and Sustainability, 16(3), 595-617. doi: 10.1007/s10668-0139496-3

Calia, P., \& Strazzera, E. (2000). Bias and Efficiency of Single vs. Double Bound Models for Contingent Valuation Studies: A Monte Carlo Analysis. Applied Economics, 32(10), 1329-1336. doi: 10.1080/000368400404489

Chuen-Khee, P., \& Othman, J. (2010). Household demand for solid waste disposal options in Malaysia. International Journal of Environmental, Ecological, Geological and Marine Engineering, 4(7), 35-40. Retrieved from http://waset.org/publications/5977/householddemand-for-solid-waste-disposal-options-in-malaysia

Coulibaly, O., Nouhoheflin, T., Aitchedji, C.C., Cherry, A.J., \& Adegbola, P. (2013). Consumers' perceptions and willingness to pay for organically grown vegetables. International Journal of Vegetable Science, 17(4), 349-362. doi: 10.1080/19315260.2011.563276

Diaz, F.J.M., Pleite, F.M.C., Paz, J.M.M., \& Garcia, P.G. (2012). Consumer knowledge, consumption and willingness to pay for organic tomatoes. British Food Journal, 114(3), 318-334. doi: 10.1108/00070701211213447

Government of Nepal (GON). (2008). Directive for national technical standards of organic agriculture production and processing system, 2007. Kathmandu: Ministry of Agriculture and Cooperatives.

Govindasamy, R., DeCongelio, M., \& Bhuyan, S. (2008). An evaluation of consumer willingness to pay for organic produce in the Northeastern U.S. Journal of Food Products Marketing, 11(4), 3-20. doi: 10.1300/J038v11n04_02

Gregory, N.G. (2000). Consumer concerns about food. Outlook on Agriculture, 29(4), 251-257. Retrieved from http://journals.sagepub.com/doi/pdf/10.5367/000000000101293310

Grossman, M. (1972). On the concept of health capital and the demand for health. The Journal of Political Economy, 80(2), 235-255. Retrieved from http://economics.sas.upenn.edu/ hfang/teaching/socialinsurance/readings/Grossman72( 3.1).pdf

Grunert, S.C., \& Juhl, H.J. (1995). Values, environmental attitudes and buying of organic food. Journal of Economic Psychology, 16(1), 63-72. Retrieved from http://www.sciencedirect.com/science/article/pii/0167487094000348

Harper, G.C., \& Makatouni, A. (2002). Consumer Perception of Organic Food Production and Farm Animal Welfare. British Food Journal, 104(3/4/5), 287-299. doi: 10.1108/00070700210425723

Hughes, D. (1995). Animal Welfare: The Consumer and the Food Industry. British Food Journal, 97(10). doi: 10.1108/00070709510104529

Hughner, R.S., Mcdonagh, P., Prothero, A., \& Shultz II, C.J. (2007). Who are Organic Food Consumers? A Compilation and Review of Why People Purchase Organic Food. Journal of Consumer Behaviour, 6, 1-17. doi: 10.1002/cb.210

Jeanty, P.W. (2007). Constructing Krinsky and Robb Confidence Intervals for Mean and Median Willingness to Pay (WTP) Using Stata. Retrieved from: http://repec.org/nasug2007/pwj_nasug07.pdf

Mitchell, R. C., \& Carson, R. T. (1989). Using Surveys to Value Public Goods: The Contingent Valuation Method. Washington, DC: Resources for Future. 
Morgera, E., Caro, C. B., \& Duran, G. M. (2012). Organic agriculture and the law. Retrieved from http://www.fao.org/docrep/016/i2718e/i2718e.pdf

Nandi, R., Bokelmann, W., Gowdru, N.V., \& Dias, G. (2016). Factors influencing consumers' willingness to pay for organic fruits and vegetables: Empirical evidence from a consumer survey in India. Journal of Food Products Marketing, 22, 1-22. doi:10.1080/10454446.2015.1048018

Narine, L.K., Ganpat,, W., \& Seepersad, G. (2015). Trinidadian consumers' willingness to pay for organic tomatoes. Journal of Agribusiness in Developing and Emerging Economies, 5(1), 76-91. doi: 10.1108/JADEE-04-2013-005

Ortelli, D., Edder, P., \& Corvi, C. (2004). Multiresidue analysis of 74 pesticides in fruit and vegetables by liquid chromatography-electrospray-tandem mass spectrometry. Anayitica Chimica Acta, 520:33-45. doi: doi:10.1016/j.aca.2004.03.037

Pokharel, D.M., \& Pant, K.P.(2009). Perspectives of organic agriculture and policy concerns in Nepal. The Journal of Agriculture and Environment, 10. Retrieved from http://www.nepjol.info/index.php/AEJ/article/viewFile/2135/1965

Rana Bhat, B. (2008). Opportunitiy and challenges of organic certification Ssystem in Nepal. In P. Chaudhary; K. Aryal and D. Tharu (Eds.), Opportunities and Challenges of Organic Production and Marketing in South Asia. Paper presented at National Policy Dialogue, pp. 104-108. Kathmandu: NPG

Schifferstein, H.N.J., \& Oude Ophuis, P.A.M. (1997). Health related determinants of organic food consumption in the Netherlands. Food Quality and Preference, 9(3), 119-133. Retrieved from http://www.sciencedirect.com/science/article/pii/S095032939700044X

Sriwaranun, Y., Gan, C., Lee, M., \& Cohen, D.A. (2015). Consumers' willingness to pay for organic products in Thailand. International Journal of Social Economics, 42(5), 480-510. doi: 10.1108/IJSE-09-2013-0204

Stan, H.J. (2000). Pesticide residue analysis in foodstuff applying capillary gas chromatography with mass spectrometric detection-state-of-the-art use of modified DFG-multimethod S19 and automated data evaluation. Journal of Chromatography A, 892(1-2), 347-377. doi: 10.1016/s0021-9673(00)308-3

Wandel, M., \& Bugge, A. (1997). Environmental concerns in consumer evaluation of food quality. Food Quality and Preferences, 8(1):19-26. Retrieved from http://www.sciencedirect.com/science/article/pii/S0950329396000043

Yiridoe, E.K., Bonti-Ankomah, S., \& Martin, R.C. (2005). Comparison of Consumer Perceptions and Preference toward Organic versus Conventionally Produced Foods: A Review and Update of the Literature. Renewable Agriculture and Food Systems, 20(4), 193-205. doi: 10.1079/RAF2005113 